\title{
Nurses` perception regarding the use of technological devices in critical care units
}

\author{
Lara Adel ${ }^{1}$, Magda Mohamed ${ }^{2}$, Magdy Ali , Dina sobh ${ }^{4}$ \\ ${ }^{1 .}$ Clinical instructor at health technical institute, Port- Said City. Arab Republic of Egypt. \\ ${ }^{2}$. Professor of medical-surgical nursing, Faculty of Nursing, Ain Shams University. Arab Republic of Egypt. \\ ${ }^{3}$ Professor of Anesthesia and Intensive Care, Faculty of Medicine, Suez Canal University. Arab Republic of \\ Egypt. \\ ${ }^{4}$ Lecture of medical-surgical nursing, Faculty of Nursing, Port Said University. Arab Republic of Egypt.
}

Koko.mido22@yahoo.com

\begin{abstract}
Technology creates challenges and crises for nurses and nursing and may dehumanize the caring of the patients. This means that technology may constitute a risk those patients will not be perceived as human beings in such a technological environment as ICU.
\end{abstract}

The aim of the study was to assess the nurses 'perception regarding the use of technological devices in the critical care units. The present study was descriptive

Research study. It was conducted in critical care units of Port-Said general Hospital, El-Zohoor hospital, PortFoad hospital, El-Mabarrah hospital and El-Tadamon hospital. The study samples consisted of 89 nurses working in the previous settings. The data was collected through structural questionnaire to assess nurses 'perception about positive and negative aspects of using technological devices in critical care units.

The results revealed that almost of nurses were had high perception of positive aspects, while almost of them were had low perception of negative aspects regarding the use of technology. The result revealed that statistically significant relation between nurses 'positive perception of using technology and their training and there was no statistically significant relation between nurses 'positive and negative perception of using technological devices.

The study recommended different strategies that enhance nurses 'perception related to the use of technological equipment in critical care unit.

Key words: Nurses `positive and negative perception - Technological devices - Critical care unit

\section{Introduction}

Technology is the making, modification, usage, and knowledge of tools, machines, techniques, crafts, systems and methods of organization, in order to solve a problem, improve a preexisting solution to a problem, achieve a goal or perform a specific function. It can also refer to the collection of such tools, machinery, modifications, arrangements and procedures (Eric, 2006). Critical care unit is a place where the challenge of machine technology in nursing which provide life support to patients and is vital to patient care management. (Reda, 2001). A critical care unit is a high-technology environment and technological developments become incorporated into nursing practice .Accordingly the use of technological devices can ensure better outcomes for patients' health and decrease morbidity and mortality. Also must be noted that the critical care nurse needs not only to be aware of what benefits the technology holds for the patient, but also what adverse effects (Samaher, 2008). The Institute of Medicine (IOM) suggests that quality health care must be safe, patient-centered, timely, efficient, effective, and equitable. These goals for excellence in health care help guide the use and development of technology in the acute and critical care setting (Elizabeth, 2010).

\section{Significance of the study:}

Critical care nurses will need to keep pace with the latest information and develop skills to manage new treatment methods and technologies. As issues relating to patient care become increasingly complex and new technologies and treatments are introduced, critical care nurses will need to become ever more knowledgeable (Morton et al., 2005).On the same time nurses play a vital role in critical care units and as a result of advancement of science we can say that technology is involved in the most of nursing care received for critically ill patient. It was important to be aware of the effect of technology and needed to assess current perception of nurses about the effect of technology in critical care units to help them to enforce on positive effects and reduce negative effects in order to keep the patient in optimal health status. From this aim the study would be done.

Aim of study

This study aimed to assess nurses ' perception regarding the use of technological devices in the critical care units. 
Nurses `perception regarding the use of technological devices in critical care units

\section{Research questions}

To achieve the aim of this study, the following research questions were formulated:

- What is the nurses' perception about positive aspect regarding the use of technology in the critical care units?

- What is the nurses' perception about negative aspect regarding the use of technology in the critical care units?

- What is the relationship between these perception and demographic characteristics?

\section{Research Design}

\section{Subjects and methods}

A descriptive study design was used to conduct this study

Settings: general Intensive care units (ICU) and cardiac care unit (CCU) of Port-Said General Hospital, ElZohoor Hospital, Port-foad hospital, El-Mabarrah Hospital and El-Tadamon Hospital.

Samples: A convenience sample was used in this study which consisted of 89 nurses (males and females) who were working in the previous setting.

Tools of data collection: Three tools were used in the study that was adopted from (Noh $\mathbf{C}$ et al., 2002, Kiekkas $P$ et al., 2006, Wikstrom A et al., 2007 and Samaher L, 2008).

Tool I: Socio-demographic Data Sheet:

It was developed by the researcher, and included data related to age, gender, level of education, years of experiences and training courses on technological equipment... etc.

Tool II: Structured questionnaire sheet to assess positive aspects of using technology which divided into:

- Positive aspect of using technology on patient such as (higher care effectiveness, technological equipment directs and controls medical treatment....etc).

- Positive aspect of using technology on nursing practice knowledge and skill such as (ease of completion of nursing duties, improves nurse's knowledge and skill....etc).

- Positive aspect of use technology on nurse such as (increase prestige of nurses, technological equipment is the eyes and hands of nurse...etc).

Tool III: Structured questionnaire sheet to assess negative aspects of using technology which divided into:

- Negative aspect of use technology on patient such as (increase patient risk from improper handling of equipment, ignoring physical needs of patient......etc).

- Complexity using technology such as (Nurse must be competent in managing technology and interpreting technological data, technology is complicate and not easy to handle......etc).

- Negative aspect of use technology on nurse and nursing care such as (Increase nurse's psychological stress, technology restricts autonomy of nurses in making decision....etc)

Scoring system of Knowledge questionnaire sheet:

The responses from "strongly agree" to "strongly disagree" were scored respectively from 5 to 1 . The scores of the statements of each type were summed-up, converted into percent score, and the total divided by the number of the items, giving a mean score for each type of perception (positive/negative). The perception was considered high if the percent score was $60 \%$ or more (corresponding to "strongly agree/agree,") and low if less than $60 \%$ (corresponding to "uncertain," and "strongly disagree/disagree,").

\section{(II) Operational Design:}

The Operational design includes preparatory phase and a pilot study

Preparatory Phase:

It was included revision of related literature, and theoretical knowledge of various aspects of the study using books, articles, internet periodicals and magazines to develop the tools for data collection. The tool was tested for content validity by 7 expert nurse educators from the Faculty of Nursing in Ain shams University, Alexandria University and a second phase, to check for clarity,

A pilot study involving 2 instructors in technical health institute in emergency department. The tool was also tested for reliability by test- retest technique; the correlation coefficient was $(84 \%)$.

Pilot Study:

A pilot study was carried out after development of data collection tool and it was applied on a sample of "9" nurses working in previously selected settings , and was conducted one month before embarking on the field of the working of the study. After obtaining the result of the pilot study, the necessary modifications were done and the final form was developed. The nurses in the pilot study were not included in the main sample.

Field of the Work:

Data were collected from March to May 2013m five days a week from Saturday to Thursday at morning shift from 8:00 Am to 2:00 pm and afternoon shifts from 2:00 pm to 8:00 pm and nurses were recruited conveniently. Data were collected using written questionnaire sheet for each nurse that lasted approximately between 20-30 minutes.

(III) Administrative Design: 
An official permission to conduct the study was obtained from the head of Critical care units of the selected hospitals, written consents were obtained from the matron, verbal consents were obtained from head nurses of the selected setting and each participant (nurses) to be included in the study after explaining clarification of the nature and purpose of the study.

\section{Ethical Consideration:}

The aim of the study has been explained to directors, physicians and staff nurses at critical care units of the concerned hospitals before asking them to participate in the study, stressing on confidentiality of the collected information. The researcher emphasized that the participations were absolutely voluntary and each nurses have the right to withdraw from the study at any time with no questions asked, as well as confidentiality was assured.

\section{Statistical Design:}

Data entry and statistical analysis were done using SPSS 16.0 statistical software package. Data were presented using descriptive statistics in the form of frequencies and percentages for qualitative variables, and means and standard deviations and medians for quantitative variables. For presentation of data, the scale of perception was compressed into 3 points: "strongly agree/agree," "uncertain," and "strongly disagree/disagree." Qualitative categorical variables were compared using chi-square test. Whenever the expected values in one or more of the cells in a $2 \times 2$ tables was less than 5, Fisher exact test was used instead. In larger than $2 \times 2$ cross-tables, no test could be applied whenever the expected value in $10 \%$ or more of the cells was less than 5 . Statistical significance was considered at $\mathrm{p}$-value $<0.05$.

\section{Results:}

Table (1): Socio-demographic characteristics of nurses in the study sample ( $n=89)$

Table (1) shows that more than half of nurses in the study samples (55.1\%) were at age group less than 25 , regarding nursing qualification, the majority of study sample $(87.6 \%)$ had nursing school diploma, and In relation to experience, about one third of the study sample (38.2\%) had experience in critical care unit between $1-5$ year.

Table (2): Percentage distribution of nurses' perception regarding the positive aspects of using technology $(\mathbf{n}=\mathbf{8 9})$

Table (2) reveals that the majority of study sample (94.4\%) were agree on positive aspect related to using technological devices produce high patient safety through prompt and proper recognition of complications and adverse effects (mean score $4.3 \pm 0.6)$, (14.6\%) were uncertain on positive aspect with using technological devices there are faster completions of nursing duties through performing it in a shorter amount of time (mean score $4.1 \pm 0.8)$ and $(50.6 \%)$ were disagree on positive aspect related to the using technological devices improve of nurse's knowledge and skills that allow a higher competence of nurses (mean score $2.9 \pm 1.4$ ).

\section{Table (3): Percentage distribution of nurses' perception regarding the negative aspects of using} technology $(\mathbf{n}=\mathbf{8 9})$

Table (3) indicates that nurses in the study sample identified some of the negative aspects of using technology, while nurses were not aware about most the negative aspect of using technology. Almost of them (83.1\%) were disagree negative aspect related to using technological devices extract attention from patient through focusing of interest on equipment and technical skills with the mean score $2.1 \pm 0.9$. Also almost of them $(83.1 \%)$ were disagree negative aspect related to using technological devices extract attention from patient through ignoring physical needs of patient with the mean score $2.1 \pm 0.9$ and almost of them $(83.1 \%)$ were disagree negative aspect related to using technology devices increase overall hospitalization cost with the mean score $2.1 \pm 0.9$. On the other hand, most of them $(92.1 \%)$ were agree negative aspect related to increase in using technological devices has downgraded the nursing profession, but only $(6.7 \%)$ of them disagree, and (1.1\%) uncertain with the mean score $4.2 \pm 0.8$.

Table (4): Relation between nurses' positive perception of technology use and their training $(n=89)$

Table (4) represents that there were statistically significant relation between nurses' positive perception of technology use and training on individual equipment, training on ventilator and training on defibrillator whereas $\mathrm{p}<0.05$

\section{Discussion:}

The result of the current study revealed that the majority of the study samples were female with diploma nursing school; this might elaborate the current condition of nursing qualification. There age were less 25 years old which might explain that they are young and tolerate the nature of critical atmosphere of work and this is important because those had received the recent knowledge about technology. In comparison with Kiekka et al. (2006) study on critical care nurses in Patras, Greece, they found that the majority of their study participants were women, registered nurses, working in adult ICU, age ranging from 23-42 years.

The result of the study showed that more than three quarter of the studied group are agreed when asked about "Using technological devices produce higher care effectiveness", "Technological devices direct and control medical treatment", and about "Using technological devices produce higher patient safety", this is results may be related to 
nurses` daily experiences with technology, that provide them with accurate information about patients and help in controlling medical treatment. This will provide them with sense of safety for patients. This result are supported by the findings of many previous studies, which include, Wikstrom et al. (2007) findings who said that technology seemed to be considered decisive as it directs and controls medical treatment and it make treatment more secure. However, this findings is in disagreement with IOM (2001) who showed that the quality of care reveals a health care system that frequently falls short in its ability to apply new technology safely and appropriately

The present study findings elaborate that more nurses are agreed when ask about "With using technological devices there are faster completions of nursing duties and with less nurse's fatigue and work load". This is findings reflect positive perception of the studied group toward positive aspect of using technology because using technology help nurses to work with several patients at the same time. In agreement, Turisco \& Rhoads (2008) found that technology help to create a better work environment and increased job satisfaction by improving efficiency, safety, easy, faster and quality of care.

Current study findings more than half of the studied group was agreed when asked about "Using technological devices increase prestige of nurses by improving of image and opinions other people have about the professional role of nurses. It reflects positive perception elicited toward the statement. This may be due to improving the imaging of nurse in front of patient and family because nurses know and work with unknown things to them. On the same line Samaher (2008) who found that nurses agreed that "technology increase prestige of nurses". But it is stand in opposite to Kiekkas et al. (2006) who found that nurses disagreed that devices could increase their prestige.

The present study findings elaborate that, positive perception elicited toward the statement "Using technological devices enhance nurse cooperation with other of health team" because the technology facilitate and enable comprehensive all information about the patient when they need and where they need it. The result is supported by Mandl, Szolovits, \& Kohane (2001) who found that technology is extremely important that all clinicians are aware of past and current medical histories when one patient is treated by several health care providers.

Current study findings illustrated nurses agreed on the statement "Using technological devices increase patient risk from errors of health team personnel through Improper handling of equipment and misinterpretation of data provided by machines". This is positive perception related to those nurses was aware to these risks and may be exposed to them. These findings are in contrast with Kiekkas et al. (2006) who found that when asked about the negative effects of equipment, the participants agreed that there is increased patient risk due to human errors or mechanical faults, increased stress and decreased autonomy. The recognition of increased risk did not contradict the contribution of devices to patient safety, because safety presupposes proper equipment function. It is remarkable that nurses attributed a higher risk to mechanical faults than personnel errors, on the other side Samaher (2008) who found that nurses disagreement on that technology increase patient risk from improper handling of equipment or misinterpretation of data

Other negative perception was revealed by current study toward the negative aspect of using technology that "Nurse must be competent in managing technological equipment and interpreting technological data". This result may be related to that nurses were not aware to importance to competence of nurse with machine in technologically demanding environments are the ultimate expression of nursing as caring. In agreement with this, Linder (2000) stated that, since there have been dramatic advances in technology; clinical education has to change in order to respond to them.

Therefore, these results are quite alarming given the negative perception regarding negative aspects of using technology because nurses disagreed that "Using technological devices extract attention from patients through focusing of interest on equipment and technical skills and ignoring physical needs of patients". This clarify that nurses using technological equipment without take in consideration that machine complexity which can lead to human errors, and this is result stand in opposite to pervious findings in current study that nurse agreed that using technological devices increase patient risk from errors of health team personnel through Improper handling of equipment and misinterpretation of data provided by machines and this is refers to disorientation toward technical environment that cause stress toward nurses and patient. This findings of the study is supported by Samaher (2008) who found that nurses also disagreed that technology cause focusing of interest on equipment and technical skills and ignoring physical needs of patients.

Nurses in the current study agree that "Using technological devices loss of human sensitivity about patients by Diminishing of interest about emotional and psychosocial needs of patients" and in the same time they disagreement that "Using technological devices loss of human sensitivity about patients by neglect human characteristics of patients". These finding refers to disorientation of nursing toward technological equipment that affect on human sensitivity about patients. This finding was disagreement with, Wassif (2007) who found that dehumanization is current challenge and the nurses need to retain focus for nursing and regarding the patient, the body, mind, spirit of this patient.

The relation between received training on each technological equipment as individual and perception regarding positive aspects of using technology were statistically significant. Also training on ventilator and training on 
defibrillator. This is may be related to improved experience regarding technology by training. Therefore, training programs improved their perception. This current finding is supported by $\mathbf{O}^{\top}$ Connell et al. (2004) who found in study on training needs of intensive care unit nurses to use computerized equipment demonstrated that nurses ' level of confidence in using computerized technologies was clearly related to their years of experience.

From this study, it can be concluded that:

\section{Conclusion}

- The majority of nurses had higher perception regarding to positive aspects of using technological devices on the other side the majority of nurses had lower perception regarding to negative aspects of using technological devices in critical care units.

- There were statistically significant relations between nurses' positive perception of using technology and their training.

\section{Recommendations}

Based on the result of this study the following recommendations are suggested:

Recommendations for Nursing Practice:

(1) Improve and update the Nurses' knowledge about positive and negative aspects of using technology in critical care units through:

- Encourage nurses to attend regular, formal in-service educational programs to update their knowledge about technological devices.

- Encourage nurses to attend national and international congresses, seminars, symposiums and workshops in the field of technological equipments in critical care units to be aware about the new in technology.

(2) Specific books, handouts and slides include comprehensive information about technological devices in Arabic language should be available

(3) Developing training materials to increase the motivation of nurses to accept their training.

(4) Continuous and strict observation of nurses during work and continuous evaluation of their practice and correction of wrongs which affect on patient.

(5) Encourage nurses to initiate self-evaluation after using technological equipment continuously.

(6) Employing only qualified and trained personnel in critical care units.

(7) Staffing should be increased to give nurses chances to training without stress.

Recommendations for Nursing Educational (undergraduate and continued):

- Nursing curriculums must include concept of technological devices in critical care units which include knowledge and skills about technology, with great emphasis on application through adequate training.

- Nursing curriculums must include concept of nursing ethics and nursing history to improve students' motivation and attitudes especially for history of technology in health care as totality and in critical care units as specific, also must include new technology which acts as new trends.

Recommendations for Future Studies:

- An ongoing, well-structured education program for nurses about positive and negative aspects of using technology should be initiated in critical care units.

- Replication of this study using larger probability sample and different settings of the study is recommended.

- Further researches needed for investigate effect of the nurses' perception about using technology in ICU.

\section{Corresponding Author:}

Dr. Dena ELtabey Sobeh

Lecturer of Medical Surgical Nursing

Port Said University- Faculty of Nursing

Port-Said- Egypt

\section{References}

[1]. Elizabeth A (2010): Patient safety technology: AACN Advanced Critical Care Volume 20, Number 2, pages 128-132.

[2]. Eric S (2006): Article about Technik Comes to America: Changing Meanings of Technology before1930 pp. $486-512$ | 10.1353/tech.2006.0201. available at: http://en.wikipedia.org/wiki/Technology.

[3]. Institute of Medicine (IOM) (2001): Crossing the Quality Chasm: A New Health System for the 21st Century. Washington, D. C.: National Academy Press.

[4]. Kiekkas P, Karga M, Poulopoulou M, Karpouhtsi I, Papadoulas V and Koutsojannis C (2006): Use of technological equipment in critical care units: nurses ' perceptions in Greece. Journal of clinical nursing; 15(2):178-87.

[5]. Linder M (2000): The future of nursing education. Journal of nursing Education; 39, 5-12. Accessed at:1/3/2014

[6]. Mandl D, Szolovits P and Kohane S (2001): public standards and patients' control: How to keep electronic medical records accessible by private. British medical journal,322, 283-287.

[7]. Morton P, Fontaine D, Hudak C and Gallo B (2005): Critical care nursing: A Holistic Approach, 8th ed. Philadelphia: Lippincott Williams \& Wilkins; 2-22, 36-45, 536-64.

[8]. Noh C, Arthur D and Sohng K (2002): Relationship between technological influences and caring attributes of Korean nurses. International journal of Nursing Practice; 8(5):247-56.

[9]. O'Connell M, Reids B and O'Loughlin K (2004): The training needs of intensive Care Unit nurses to use computerized equipment. Faculty of Health Sciences, University of Sydney. Accessedat:http://www.chs.usyd.edu.au/conf04/submit/minipost/gx-oconn.pdf. 
[10]. Reda N (2001): Impact of technology on nursing practice in Critical Care Units. Unpublished review article, faculty of nursing, university of Alexandria; 1-3.

[11]. Samaher L (2008): Nurses' Perception Regarding the Use of Technological Equipment in the Critical Care Units. Journal of American Science, published 2011; 7(10):545-552]. (ISSN: 1545-1003).

[12]. Turisco F and Hoads J (2008): Equipped for efficiency: improving Nursing care through Technology. California Health Care Foundation (CHCF). Accessed at: 13/1/2014.

[13]. Wassif M (2007): Caring behaviors and ability of nurses in the intensive care units. Unpublished Master thesis, Faculty of Nursing. Alexandria University; 51-8.

[14]. Wikstrom A (2007): Knowing in practice at tool in the production of intensive care. Printed in Sweden by intellect a docusys AB vastra frolunda 2007. ISBN131978-91-628-7173-4.

Table (1): Socio-demographic characteristics of nurses in the study sample (n=89)

\begin{tabular}{|l|c|c||}
\hline & $\begin{array}{c}\text { Frequency } \\
\text { No }\end{array}$ & $\begin{array}{c}\text { Percent } \\
\%\end{array}$ \\
\hline Age: & 49 & \\
$<25$ & 33 & $55.1 \%$ \\
$25-$ & $77.1 \%$ \\
$35+$ & & $7.9 \%$ \\
\hline Sex: & 10 & \\
Male & 79 & $11.2 \%$ \\
Female & & $88.8 \%$ \\
\hline Nursing qualification: & 11 & \\
Bachelor & 78 & $12.4 \%$ \\
Diploma & & $87.6 \%$ \\
\hline Job position: & 12 & \\
Head nurse & 77 & $13.5 \%$ \\
Staff nurse & & $86.5 \%$ \\
\hline Experience years in critical care units: & 25 & \\
$<1$ & 34 & $28.1 \%$ \\
$1-5$ & $38.2 \%$ \\
$>5$ & & $33.7 \%$ \\
\hline \hline
\end{tabular}

Table (2): Percentage distribution of nurses' perception regarding the positive aspects of using technology

\begin{tabular}{|c|c|c|c|c|c|c|c|c|c|}
\hline \multirow[t]{2}{*}{ Items } & \multicolumn{2}{|c|}{ Agree } & \multicolumn{2}{|c|}{ Uncertain } & \multicolumn{2}{|c|}{ Disagree } & \multicolumn{3}{|c|}{ Score $(\max =5)$} \\
\hline & No. & $\%$ & No & $\%$ & No & $\%$ & $\mathbf{M}$ & SD & Mn \\
\hline $\begin{array}{l}\text { Produce higher care effectiveness via achieving } \\
\text { better patient outcomes }\end{array}$ & 74 & 83.1 & 9 & 10.1 & 6 & 6.7 & 4.1 & 0.9 & 4.0 \\
\hline Direct and control medical treatment & 77 & 86.5 & 8 & 9.0 & 4 & 4.5 & 4.2 & 0.9 & 4.0 \\
\hline $\begin{array}{l}\text { Produce higher patient safety through Prompt and } \\
\text { proper recognition of complications and adverse } \\
\text { effects. }\end{array}$ & 84 & 94.4 & 3 & 3.4 & 2 & 2.2 & 4.3 & 0.6 & 4.0 \\
\hline $\begin{array}{l}\text { Produce higher patient safety through technology } \\
\text { makes treatment more secure. }\end{array}$ & 76 & 85.4 & 9 & 10.1 & 4 & 4.5 & 4.2 & 0.8 & 4.0 \\
\hline $\begin{array}{l}\text { Produce easy completion of nursing } \\
\text { duties through performing nursing tasks with less } \\
\text { nurse's fatigue and work load. }\end{array}$ & 72 & 80.9 & 10 & 11.2 & 7 & 7.9 & 4.1 & 1.0 & 4.0 \\
\hline $\begin{array}{l}\text { There are faster completions of nursing duties } \\
\text { through performing it in a shorter amount of time. }\end{array}$ & 73 & 82.0 & 13 & 14.6 & 3 & 3.4 & 4.1 & 0.8 & 4.0 \\
\hline $\begin{array}{l}\text { Improve of nurse's knowledge and skills that } \\
\text { allow a higher competence of nurses }\end{array}$ & 37 & 41.6 & 7 & 7.9 & 45 & 50.6 & 2.9 & 1.4 & 2.0 \\
\hline $\begin{array}{l}\text { Using technological devices increase prestige of } \\
\text { nurses by improving of image and opinions other } \\
\text { people have about the professional role of nurses. }\end{array}$ & 58 & 65.2 & 10 & 11.2 & 21 & 23.6 & 3.5 & 1.1 & 4.0 \\
\hline $\begin{array}{l}\text { Enhance nurse cooperation with other of health } \\
\text { team. }\end{array}$ & 54 & 60.7 & 12 & 13.5 & 23 & 25.8 & 3.4 & 1.3 & 4.0 \\
\hline Help to compensate the shortage of nurses & 80 & 89.9 & 4 & 4.5 & 5 & 5.6 & 4.1 & 0.8 & 4.0 \\
\hline Require high-tech skills & 78 & 87.6 & 7 & 7.9 & 4 & 4.5 & 4.2 & 0.8 & 4.0 \\
\hline $\begin{array}{l}\text { Technological devices are the eyes and hands of } \\
\text { nurse. }\end{array}$ & 80 & 89.9 & 5 & 5.6 & 4 & 4.5 & 4.1 & 0.7 & 4.0 \\
\hline Enhance patient care & 78 & 87.6 & 8 & 9.0 & 3 & 3.4 & 4.1 & 0.7 & 4.0 \\
\hline
\end{tabular}


Table (3): Percentage distribution of nurses' perception regarding the negative aspects of using technology $(n=89)$

\begin{tabular}{|c|c|c|c|c|c|c|c|c|c|}
\hline & \multicolumn{2}{|c|}{ Agree } & \multicolumn{2}{|c|}{ Uncertain } & \multicolumn{2}{|c|}{ Disagree } & \multicolumn{3}{|c|}{ Score $(\max =5)$} \\
\hline & No. & $\%$ & No & $\%$ & No & $\%$ & Mean & SD & Median \\
\hline $\begin{array}{l}\text { Increase patient risk from errors of health team } \\
\text { personnel through Improper handling of } \\
\text { equipment }\end{array}$ & 48 & 53.9 & 15 & 16.9 & 26 & 29.2 & 3.4 & 1.1 & 4.0 \\
\hline $\begin{array}{l}\text { Increase patient risk from errors of health } \\
\text { team personnel through Misinterpretation of } \\
\text { data provided by machines }\end{array}$ & 45 & 50.6 & 20 & 22.5 & 23 & 25.8 & 3.4 & 1.1 & 4.0 \\
\hline $\begin{array}{l}\text { Nurse must be competent in managing } \\
\text { technological equipment and interpreting } \\
\text { technological data }\end{array}$ & 17 & 19.1 & 14 & 15.7 & 58 & 65.2 & 2.5 & 1.0 & 2.0 \\
\hline $\begin{array}{l}\text { Increase nurse's psychological stress and } \\
\text { burnout which comes when nurse is } \\
\text { overwhelmed with the much of equipment }\end{array}$ & 23 & 25.8 & 19 & 21.3 & 47 & 52.8 & 2.7 & 1.1 & 2.0 \\
\hline Health and physical risks for nurses & 11 & 12.4 & 12 & 13.5 & 66 & 74.2 & 2.3 & 0.9 & 2.0 \\
\hline Increase the risks and complications for patient. & 27 & 30.3 & 9 & 10.1 & 53 & 59.6 & 2.6 & 1.1 & 2.0 \\
\hline $\begin{array}{l}\text { Must be taken a vacation regularly from ICU } \\
\text { pressure technology. }\end{array}$ & 18 & 20.2 & 13 & 14.6 & 58 & 65.2 & 2.5 & 1.0 & 2.0 \\
\hline $\begin{array}{l}\text { Extract attention from patients through Focusing } \\
\text { of interest on equipment and technical skills. }\end{array}$ & 10 & 11.2 & 5 & 5.6 & 74 & 83.1 & 2.1 & 0.9 & 2.0 \\
\hline $\begin{array}{l}\text { Extract attention from patients through ignoring } \\
\text { physical needs of patients. }\end{array}$ & 11 & 12.4 & 4 & 4.5 & 74 & 83.1 & 2.1 & 0.9 & 2.0 \\
\hline $\begin{array}{l}\text { Extract time from patients by devoting much } \\
\text { time on its devices. }\end{array}$ & 41 & 46.1 & 22 & 24.7 & 26 & 29.2 & 3.2 & 1.1 & 3.0 \\
\hline $\begin{array}{l}\text { Restrict autonomy of nurses in making decision } \\
\text { by increase dependence on other health care } \\
\text { professionals. }\end{array}$ & 43 & 48.3 & 6 & 6.7 & 40 & 44.9 & 3.0 & 1.2 & 3.0 \\
\hline $\begin{array}{l}\text { Loss of human sensitivity about patients by } \\
\text { Diminishing of interest about } \\
\text { emotional/psychosocial needs of patients. }\end{array}$ & 59 & 66.3 & 15 & 16.9 & 15 & 16.9 & 3.6 & 1.0 & 4.0 \\
\hline $\begin{array}{l}\text { Loss of human sensitivity about patients by } \\
\text { neglect human characteristics of patients. }\end{array}$ & 17 & 19.1 & 27 & 30.3 & 45 & 50.6 & 2.7 & 0.9 & 2.0 \\
\hline Increase overall hospitalization cost & 11 & 12.4 & 4 & 4.5 & 74 & 83.1 & 2.1 & 1.0 & 2.0 \\
\hline
\end{tabular}

Table (4): Relation between nurses' positive perception of technology use and their training $(n=89)$

\begin{tabular}{|c|c|c|c|c|c|c|}
\hline & \multicolumn{4}{|c|}{ Positive perception } & \multirow{3}{*}{$\mathrm{X}^{2}$ test } & \multirow{3}{*}{$\begin{array}{c}\text { p- } \\
\text { value }\end{array}$} \\
\hline & \multicolumn{2}{|c|}{ High } & \multicolumn{2}{|c|}{ Low } & & \\
\hline & No. & $\%$ & No & $\%$ & & \\
\hline $\begin{array}{l}\text { Had training on all technological devices as total: } \\
\text { No } \\
\text { Yes }\end{array}$ & $\begin{array}{l}46 \\
32\end{array}$ & $\begin{array}{l}85.2 \\
91.4\end{array}$ & $\begin{array}{l}8 \\
3\end{array}$ & $\begin{array}{c}14.8 \\
8.6\end{array}$ & Fisher & 0.52 \\
\hline $\begin{array}{l}\text { Had training on individual equipment: } \\
\text { No } \\
\text { Yes }\end{array}$ & $\begin{array}{l}33 \\
45\end{array}$ & $\begin{array}{l}78.6 \\
95.7\end{array}$ & $\begin{array}{l}9 \\
2\end{array}$ & $\begin{array}{c}21.4 \\
4.3\end{array}$ & 6.04 & $0.01 *$ \\
\hline $\begin{array}{c}\text { Had training on: } \\
\text { Ventilator } \\
\text { No } \\
\text { Yes } \\
\end{array}$ & $\begin{array}{l}50 \\
28 \\
\end{array}$ & $\begin{array}{r}82.0 \\
100.0 \\
\end{array}$ & $\begin{array}{c}11 \\
0\end{array}$ & $\begin{array}{c}18.0 \\
0.0\end{array}$ & Fisher & $0.01 *$ \\
\hline $\begin{array}{r}\text { Defibrillator } \\
\text { No } \\
\text { Yes }\end{array}$ & $\begin{array}{l}52 \\
26 \\
\end{array}$ & $\begin{array}{c}82.5 \\
100.0 \\
\end{array}$ & $\begin{array}{c}11 \\
0\end{array}$ & $\begin{array}{c}17.5 \\
0.0\end{array}$ & Fisher & $0.03 *$ \\
\hline $\begin{array}{c}\text { Infusion pumps } \\
\text { No } \\
\text { Yes } \\
\end{array}$ & $\begin{array}{l}65 \\
13 \\
\end{array}$ & $\begin{array}{c}85.5 \\
100.0 \\
\end{array}$ & $\begin{array}{c}11 \\
0\end{array}$ & $\begin{array}{c}14.5 \\
0.0 \\
\end{array}$ & Fisher & 0.35 \\
\hline $\begin{array}{ll}\text { ECG } & \\
& \text { No } \\
& \text { Yes }\end{array}$ & $\begin{array}{l}48 \\
30\end{array}$ & $\begin{array}{l}84.2 \\
93.8\end{array}$ & $\begin{array}{l}9 \\
2\end{array}$ & $\begin{array}{c}15.8 \\
6.3\end{array}$ & Fisher & 0.32 \\
\hline $\begin{array}{r}\text { Hemodialysis } \\
\text { No } \\
\text { Yes }\end{array}$ & $\begin{array}{c}69 \\
9\end{array}$ & $\begin{array}{c}86.3 \\
100.0\end{array}$ & $\begin{array}{c}11 \\
0\end{array}$ & $\begin{array}{c}13.8 \\
0.0\end{array}$ & Fisher & 0.59 \\
\hline $\begin{array}{ll}\text { Monitor } & \\
& \text { No } \\
& \text { Yes } \\
\end{array}$ & $\begin{array}{l}68 \\
10 \\
\end{array}$ & $\begin{array}{c}86.1 \\
100.0 \\
\end{array}$ & $\begin{array}{c}11 \\
0 \\
\end{array}$ & $\begin{array}{c}13.9 \\
0.0 \\
\end{array}$ & Fisher & 0.35 \\
\hline $\begin{array}{r}\text { Blood gases } \\
\text { No }\end{array}$ & 66 & 86.8 & 10 & 13.2 & & \\
\hline
\end{tabular}


Nurses ` perception regarding the use of technological devices in critical care units

\begin{tabular}{|c|c|c|c|c|c|c|}
\hline Yes & 12 & 92.3 & 1 & 7.7 & Fisher & 1.00 \\
\hline $\begin{array}{c}\text { Troponin measurement } \\
\text { No } \\
\text { Yes }\end{array}$ & $\begin{array}{c}70 \\
8\end{array}$ & $\begin{array}{c}86.4 \\
100.0\end{array}$ & $\begin{array}{c}11 \\
0\end{array}$ & $\begin{array}{c}13.6 \\
0.0\end{array}$ & Fisher & 0.59 \\
\hline $\begin{array}{ll}\text { Suction } & \\
& \text { No } \\
& \text { Yes }\end{array}$ & $\begin{array}{l}64 \\
14\end{array}$ & $\begin{array}{c}85.3 \\
100.0\end{array}$ & $\begin{array}{c}11 \\
0\end{array}$ & $\begin{array}{c}14.7 \\
0.0\end{array}$ & Fisher & 0.20 \\
\hline
\end{tabular}

(*) Statistically significant at $p<0.05$ 